\title{
SEISMIC RETROFITTING OF MASONRY VAULT USING CFRP
}

\section{REPARACIÓN SÍSMICA DE UNA BÓVEDA DE MAMPOSTERÍA USANDO CFRP}

\section{LAURA ANANIA', ANTONIO BADALÀ2', GIUSEPPE D'AGATA ${ }^{3}$}

\author{
1 University of Catania, Italy. Ianania@dica.unict.it \\ 2 University of Catania, Italy. abadala@dica.unict.it \\ 3 University of Catania, Italy. gdagata@dica.unict.it
}

RESUMEN

Las bóvedas de mampostería representan uno de los elementos sísmicos más vulnerables de un edificio antiguo. También generalmente no posee una capacidad suficiente de redistribución de la acción sísmica entre las paredes de los edificios. En este artículo, se discute el comportamiento estructural de una bóveda de cañón de mampostería reforzada por la nueva tecnología en la aplicación de polímero reforzado con fibra de carbono (C-FRP) desde el punto de vista teórico y experimental. El C-FRP se aplica de forma que asuma una forma de $\Omega$ alrededor de un núcleo de concreto realizado en la bóveda extrados. Esta disposición permite que la bóveda acanalada reforzada CFRP resultante asuma la resistencia necesaria y la rigidez de membrana y flexión para asegurar la capacidad de redistribución de acción sísmica antes mencionada y para evitar el colapso local de la bóveda. La predicción teórica de la resistencia última se derivó de acuerdo con las ocurrencias observadas durante los experimentos (trituración de albañilería, rotura de FRP, desprendimiento, deslizamiento a lo largo de la junta de mortero). Con este objetivo, se desarrolló un nuevo enfoque paso a paso incremental de análisis de límites, teniendo en cuenta el mecanismo de falla de cizalladura en cada unión de mortero. La resistencia al cizallamiento se evalúa mediante la ley de fricción de Mohr-Coulomb para la unión de mortero y por otras relaciones de código italiano no lineales para refuerzo de $\Omega$-Wrap de CFRP. En el proceso de análisis incremental aproximado, el valor actual de la resistencia al cizallamiento depende del esfuerzo de compresión resultante del paso anterior.

PALABRAS CLAVE: arco, bóvedas, estructura de mampostería, fortalecimiento, FRP, análisis de límites, límite inferior, adaptación sísmica, regla de flujo de fricción no asociativa.

\begin{abstract}
Masonry vaults represent one of the most seismic vulnerable element in an ancient building. It also generally does not possess an adequate capability of redistribution of the seismic action among the walls of the buildings. In this paper, the structural behaviour of a masonry barrel vault strengthened by a new technology in applying Carbon Fiber Reinforced Polymer (C-FRP) is discussed from both theoretical and experimental point of view. The C-FRP is applied such as to assume an $\Omega$ shape around a concrete core realized at the vault extrados. This arrangement allows the resulting CFRP reinforced ribbed vault to assume the necessary strength and membranal and flexural rigidity so as to ensure the aforementioned seismic action redistribution capability and to avoid local collapse of the vault. A theoretical prediction of ultimate strength was derived in agreement with the occurrences observed during the experiments (masonry crushing, FRP rupture, debonding, sliding along the mortar joint). To this aim, a novel incremental step-by-step lower bound limit analysis approach was developed taking into account for the shear failure mechanism at each mortar joint. The shear strength is evaluated by the Mohr-Coulomb friction law for the mortar joint and by other nonlinear Italian Code relations for CFRP Q-Wrap reinforcement. In the approximated incremental analysis process the current value of the shear strength, depend on the compressive stress resulting from the previous step.
\end{abstract}

KEYWORDS: arch, vaults, masonry structure, strengthening, FRP, limit analysis, lower bound, seismic retrofitting, non-associative friction flow rule. 
INTRODUCTION

Masonry vaults are usually highly vulnerable to seismic hazard, as demonstrated in the recent past by the collapses of many masonry churches during the Umbria Marche (1997-1998) and L'Aquila (2009) earthquakes.

It also generally does not possess an adequate capability of redistribution of the seismic action between the masonry piers of the buildings.

So, nowadays, the theme of the seismic retrofitting of historical buildings, in presence of these structural components, is playing an increasing role, in the field of the civil engineering,.

To this aim, a new technology for the retrofitting of masonry vaults by means of

CFRP, proposed by Badalà et al. Errore. L'origine riferimento non è stata trovata. and named ' $\Omega$-WRAP is studied under analytical and experimental investigation.

The basic ideas of the " $\Omega$-Wrap" system is to give high stiffness to the CFRP strips by wrapping it around a high resistance mortar core cast and molded in site (figure 1).

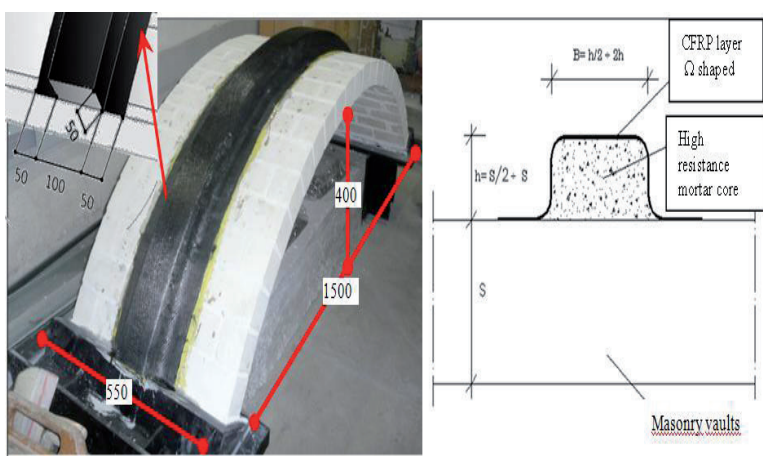

Figure 1. a) Model of the barrel vault tested, dimensions in [mm]; b) ń-Wrap reinforcement.

This reinforcement, placed at the extrados of the vault, allows preserving the precious frescoes that commonly, in the historic masonry buildings, adorn the intrados.

In addition, it presents a higher resistance against delamination respect to the canonic FRP - strip based reinforcement, as considered in the technical document CNR-DT 200/2004 [2], for two orders of reasons:

- The extrados curvature positively affects the delamination resistance due to the onset of compression normal stresses. See Basilio \& al.[3], D’Ambrisi \& al.[4], Malena \& De Felice[5], Fagone \& al.[6] ;

- The global bending stiffness of fiber -reinforced rib increases its resistance against shear induced out of plane peeling (figure. 2);

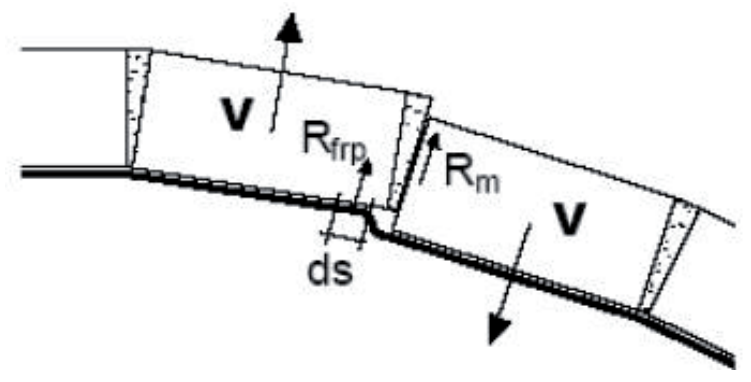

Figure 2. Shear induced out of plane reinforce peeling.

It is also under evaluation the effectiveness of another version of the proposed innovative reinforcement system, named Isolated- $\Omega$-Wrap.

This variant provides for the interposition of a neoprene bearing between the extrados of the vaults and the fiber reinforced concrete rib.

This bearing, with a thickness of a few millimeters, continuously placed

Throughout the length of the leader of the vault and having the same width of the reinforcement, is expected to allow the vault to freely deformed under daily thermal -hygrometric gradient. On the contrary, remaining unchanged the sewing effect on the collapse hinges, and the cinematic confinement effect and thus the resistance against accidental and seismic loads. Some first results about this system is available in Anania [7].

The assessment of the effectiveness of this new technique has implies the analytical and experimental investigation on several series of scaled model, as better illustrated in Anania \& al.[1].

In this paper, only a brief resume of same relevant results obtained by means of a new methodology for approaching the limit analysis of the reinforced masonry vaults, limited to the case of the non-isolated ' $\Omega$-WRAP system, is reported. From the analytical point of view, with the development of computer based numerical methods, the FEM method is largely used to simulate the complex behavior of the masonry arches and vaults even when associated to innovative material (Mahini \& Al [8]-[9]). However, this kind of analysis is often very time expensive and the input parameters of the simplified theoretical constitutive models are difficult to calibrate experimentally. For this reason, other method is actually reported in literature for the structural analysis of the masonry vaults and arches.

Among these, the one that is becoming increasingly important is the limit analysis 
(Heyman J. [10], Milani \& al.[11]-[14], Basilio [15]), that also includes the approach based on the thrust network analysis (P. Block \& al. [16], Fraternali [17]).

The analysis method proposed by Baratta \& al.[18] seems to be also interesting. In the follow, an approximated methodology for approaching the lower bound limit analysis of masonry arch (and barrel vaults), reinforced by CFRP is illustrated. It is based on the central idea of carrying out a series of lower bound limit analyses. In each of them shear strength is assumed constant and given by the MohrCoulomb limit at the corresponding compression force, in each mortar joint, resulting from the previous step.

The analytical approach is also capable of taking into account the shear mechanisms according to the dowel effect at the interface between masonry and CFRP. So, an incremental procedure was carried out in which for each single step the limit analysis problem was solved considering a constant value of the shear resistance derived taking into account the normal stress at the previous step according to Coulomb law. The proposed limit analysis method was implemented in Mathematica software to carry out numerical simulation of the experimental test conducts on the scaled barrel vault samples, described above (figure. 1).

In this paper, the limit analysis procedure is referred only to the case of barrel vaults with constant thickness and circular generatrix, reinforced by the $\Omega$-Wrap technique, although it is also valid for arch and vaults of generic generatrix and variable thickness. Further details of the application of this method to the case of unreinforced and classically CFRP strip reinforced vaults can be found in Badalà \&al.[19]-[20].

The method is based on limit analysis and uses the static theorem approach to determine the ultimate capacity of the structures analyzed by means of an optimization process.

The proposed limit analysis formulation relies on a number of assumptions necessary for the validity of the limit theorems:

- No tensile strength for both the masonry and of the mortar rib of the $\Omega^{-}$

Wrap, with rigid-perfectly plastic behaviour in compression;

- Bricks havelimited compressive strength;

- No compression and flexional rigidity of the FRP reinforcement, with rigidperfectly plastic behaviour in tension;
- Transversal plane sections conservation;

- Delamination of the CFRP is not considered explicitly.

- Constant CFRP reinforcement "dowel effect" shear strength.

- Plane geometry;

It is well known, the interface CFRP-masonry behaviour is very far from being elastic-perfectly plastic, rather it's strongly non linear with softening, as is typical for fracture cohesive mechanics. Therefore, the results obtained have to be considered only an approximation of the real load-bearing capacity of the masonry vaults reinforced by CFRP. In spite the necessary aforementioned considerations, the methodology results in very good agreement with available original experimental data.

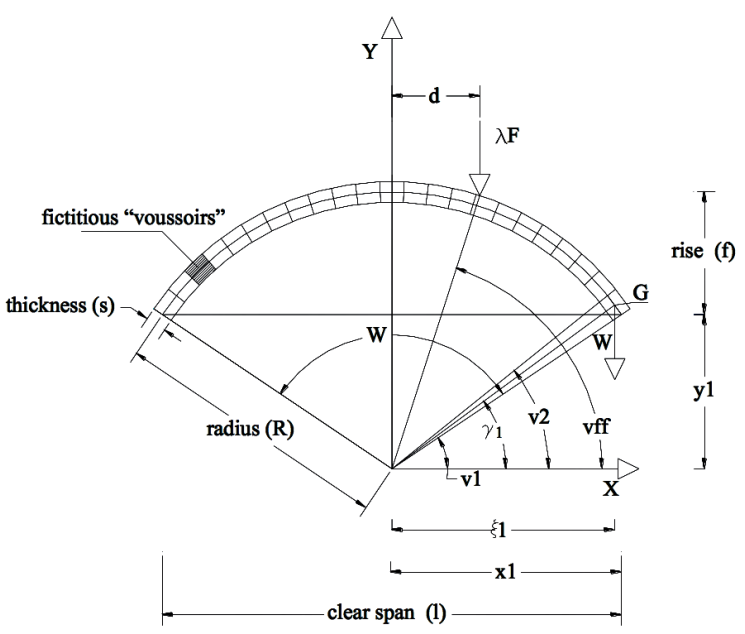

Figure 3. Geometry discretization.

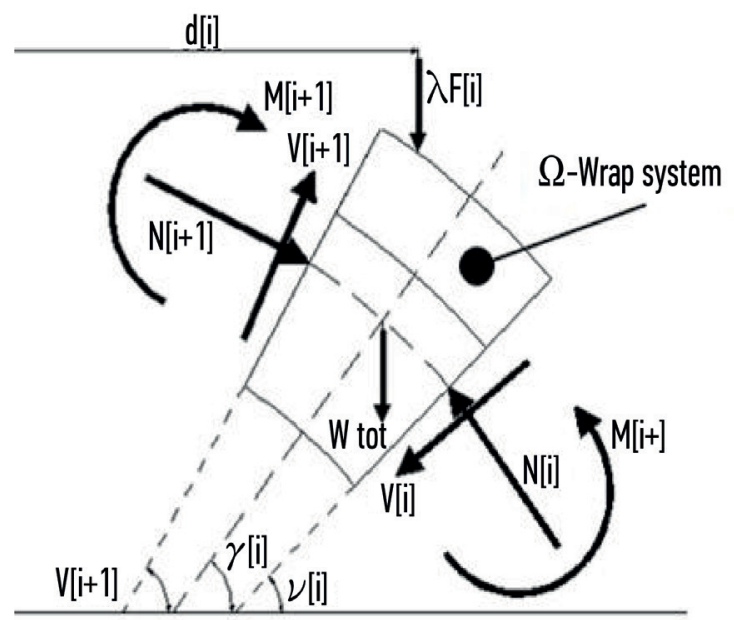

Figure 4. Forces acting on the single fictitious voussoir of arch.

THE GEOMETRY

For that purpose, the geometry is described by decomposing the entire masonry vault (or arch) 
in a series of equally spaced short segments (or fictitious "voussoirs") limited by sections oriented perpendicularly to the axis (figure. 3). figure 4 shows the forces acting on theelementary fictitious voussoir; where $\mathrm{N}, \mathrm{V}, \mathrm{M}$ indicate the characteristics of internal forces, $\mathrm{W}$ is the weight of the voussoir (including $\Omega$-Wrap system) and $\mathrm{F}[\mathrm{i}]$ is the force acting on it, amplified

by $\lambda$ and applied at the distance $d[i]$ from the " $y$ " axis of symmetry. There are accordingly $3(\mathrm{n}+1)$ internal forces and $3 \mathrm{n}$ equilibrium equations, being $n$ the number of voussoir. With an appropriate choice of the three undetermined unknowns, the equations of equilibrium can be conveniently reformulated obtaining the internal forces as a function of them.

\section{THE M-N DOMAIN}

Theadmissibilitydomain of interaction between bending moment and axial force ( $\mathrm{M}-\mathrm{N}$ domain) is calculated taking into account that the limit strength in tension of CFRP, assumed herein rigid- perfectly plastic as aforementioned, is evaluated with CNR-DT200/2004 formulas [2].

The $\mathrm{M}-\mathrm{N}$ domain, for a rectangular section reinforced by the $\Omega$-Wrap reinforcement, is derived considering four different mechanisms both for negative and positive bending moment, for a total of eight expressions. With reference to figure. 5, we have:

\begin{tabular}{|c|c|}
\hline $\mathbf{s}$ & Thickness of masonry arch; \\
\hline $\operatorname{Pr}$ & $\begin{array}{l}\text { Effective width of the portion of masonry barrel vault } \\
\text { collaborating with the reinforcement, evaluated according to } \\
\text { CNR-DT200/2004 with relation to a reinforcement width given } \\
\text { by } p c+2 a\end{array}$ \\
\hline he, pc & Thickness and width of $\Omega$-Wrap system \\
\hline tf & Thickness of FRP reinforcement \\
\hline bf , sup & width of FRP reinforcement at the top of $\Omega$-Wrap system \\
\hline a & $\begin{array}{l}\text { width of the FRP reinforcement swaged at the extrados of the } \\
\text { vault }\end{array}$ \\
\hline$\alpha \mathrm{fcm}$ & compressive strength of masonry \\
\hline$\sigma f \operatorname{maxb}$ & $\begin{array}{l}\text { Tensile strength of C-FRP adherent to the masonry evaluated } \\
\text { according to CNR-DT200/2004 (with account for delamination) }\end{array}$ \\
\hline ofmaxc & $\begin{array}{l}\text { Tensile strength of C-FRP adherent to the mortar core of the } \\
\Omega \text {-Wrap system, evaluated according to CNR- DT200/2004(with } \\
\text { account for delamination); }\end{array}$ \\
\hline afce & compressive strength of mortar core of the $\Omega$-Wrap system \\
\hline
\end{tabular}

Considering a positive bending moment, four mechanisms can be assessed, according with the position of the neutral axes, obtaining four pair of parametric equations (1-8). In a same way it is possible to determinate the other four pair of parametric equation of $\mathrm{N}-\mathrm{M}$ domain for negative curvature.
From each pair of parametric expressions it is easy to get the limit static admissibility conditions, for bending moment and axial force, in the form: $M \leq \operatorname{Mi}(\mathrm{N})$, with $\mathrm{i}=1,2, . .8$.

The convex limit domain $\mathrm{M}-\mathrm{N}$ envelope of the eight functions $\operatorname{Mi}(\mathrm{N})$, obtained for the case of $\Omega$-Wrap system reinforcement is compared in the Fig. 6 with the one of the unreinforced masonry vault and of the classical reinforcement with only one strip, with the same width of $\Omega$-Wrap $(200 \mathrm{~mm})$ and the same total specific weight $(300 \mathrm{~g} / \mathrm{m} 2)$ of uniaxial fabric of CFRP, attached at the extrados of the vault.

TENSE INTRADOS

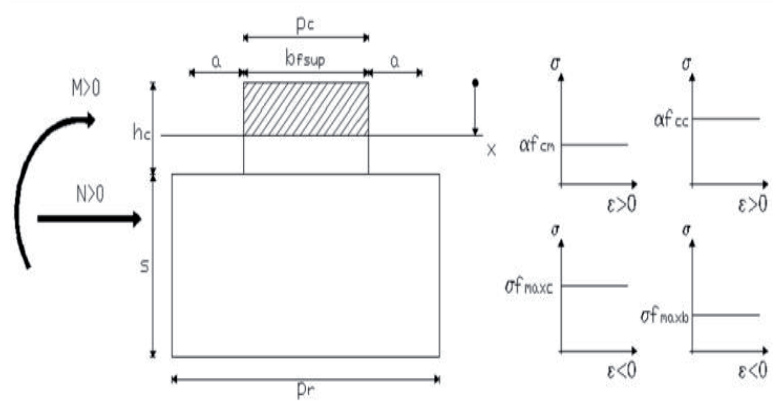

Figure 5. Generic transversal of the $\Omega$-Wrap system: Positive bending.

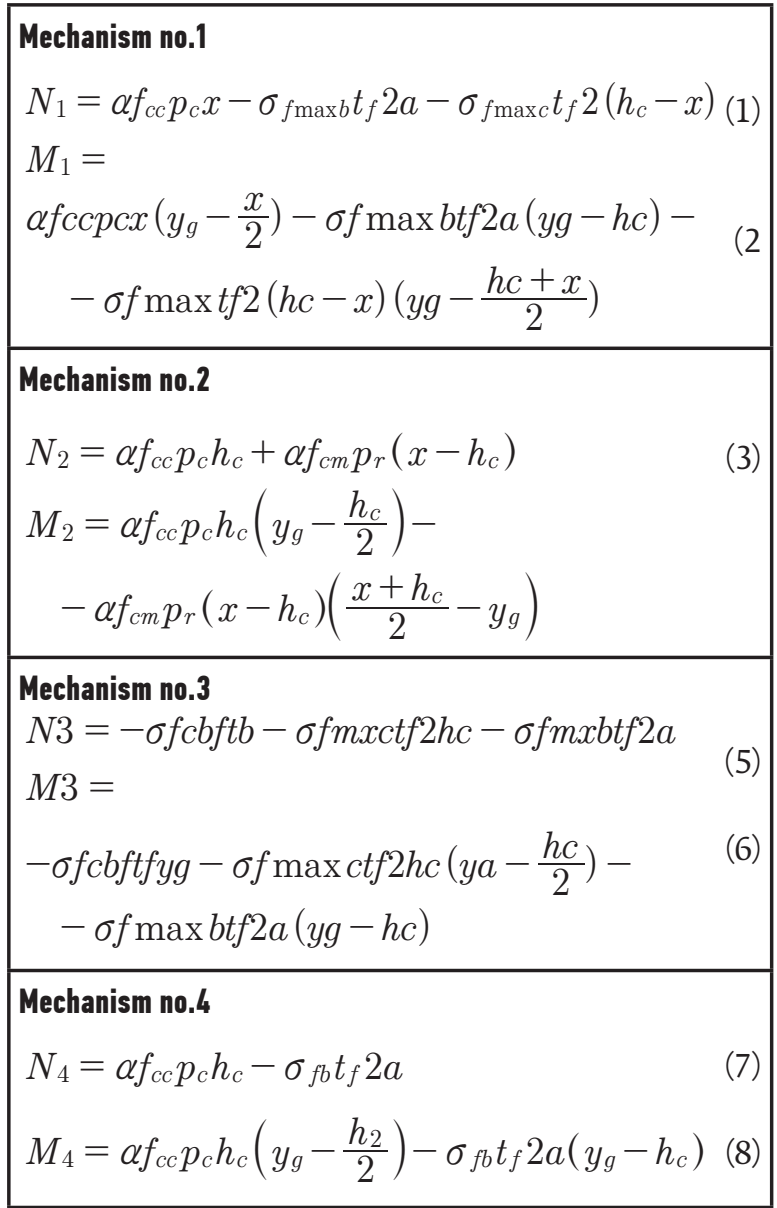




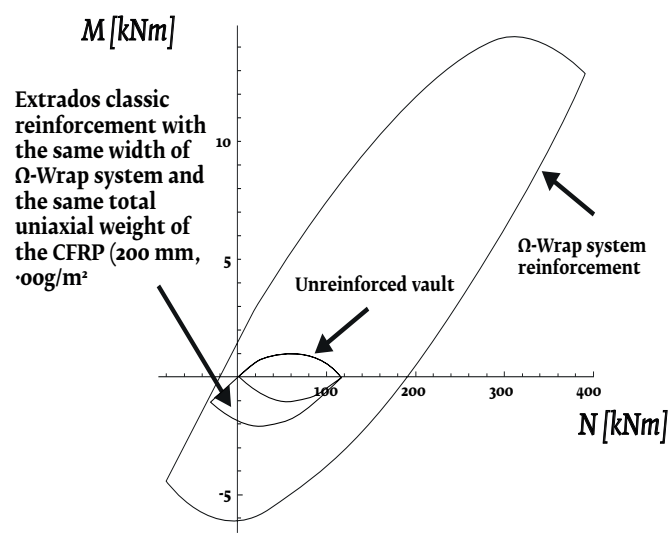

Figure6. Comparison of the interaction domain $\mathrm{M}-\mathrm{N}$ for different reinforcing system of a masonry barrel vault.

SHEAR STRENGTH

Sliding consists in relative movements of two parts along the mortar joint and it occurs when the friction mechanism is not capable of balancing the shear of the external load on the cross section with a corresponding shear force. The shear resistance of the $\Omega$-Wrap reinforced masonry vault is the sum of three different contributions:

1. The shear strength of the mortar joint, evaluated according to the Italian Code D.M. 14/01/2008[21], with the Mohr -Coulomb friction low, with a friction coefficient of 0.4. As well known, this contribution is strongly compression normal stress dependent and causes the limit analysis to be rigorously considered with a non-associated flow - rule.

2. The shear strength of the fiberre inforced concrete rib. It can be evaluated, in conformity with the Italian Code D.M. 14/01/2008[21] and CNR-DT 200/2004[2], as sum of only two contribution, because of the absence of steel shear reinforcement:

- The shear resistance of the concrete (mortar) rib, evaluated with the Mohr-Coulomb friction low, with a friction coefficient of 0.15 .

- The shear resistance of the fiber reinforcement, evaluated in conformity with the Italian Code D.M. 14/01/2008[21]. In this case can be adopted the formulation valid for the U-wrap and corresponding to the Moersch's truss model, assuming an inclination of the compressed rod of 45 degrees.
3. Dowel-effect, Pd , of the portion of CFRP folded on the extrados of the vault. Refer to Badalà \& al.[19] for more details.

FORMULATION OF THE OPTIMIZATION PROBLEM

The lower bound limit analysis formulation leads to the follow optimization Comparison of the interaction domain $\mathrm{M}-\mathrm{N}$ for different

problem to finding the limit multiplier $\lambda$ of the applied load system:

$$
\begin{aligned}
& \lambda_{c}=\max _{\lambda, x} \lambda \\
& \text { sto }\left\{\begin{array}{c}
M[i] \leq M_{j}(N[i]) ; \\
M[i] \geq M_{k}(N[i]) ; \quad j=1,2,3,4 \\
{[V] \leq V_{R d, m}+V_{R d, c}+P_{d, a}} \\
k=5,6,7,81,2, \ldots, n+1
\end{array}\right\} \text { (9) }
\end{aligned}
$$

In this formulations with " $\mathrm{i}$ " is indicated each of the joints of the vault, being " $\mathrm{n}$ " the number of fictitious voussoirs, while "j" and "k" are the two series of the four relations for the $\mathrm{M}-\mathrm{N}$ domain, in explicit form, for positive and negative sign of the rotation of the cross section, respectively. The vector $\mathrm{X}$ collects the three independent interfacial forces that determine all the other internal force in the vault. The functional dependence from the variables $\Omega$ and $\mathrm{X}$ is omitted for simplifying the notation. This formulation is valid for fixed values of the shear resistance in each section of the vaults, so we are within the framework of the validity of the Radenkovic's second theorem for non-associated flow rules [20]. The proposed algorithm consists of the follows steps:

1. Solving the problem (9) for a value of the shear strength of each section of the vault corresponding to a null value of the axial force.

2. Solving again the same problem (9), considering a shear resistance corresponding to compressive stress found in conjunction with the limit load obtained from the previous problem resolution;

3. Repeated step 2) until result satisfies the two following conditions:

a. No more change of the collapse mechanism;

b. Convergence of the resulting limit load multiplier to the assumed final value, within a fixed numerical tolerance.

At each step the average value of the normal stress acting on the rib and masonry sections, respectively, is computed in approximate way 
from the linear distribution obtained applying the Navier's law to the homogenized cross section.

\section{EXPERIMENTAL VALIDATION OF THE PROPOSED} ANALYTICAL METHOD

To validate the proposed method, a series of experimental tests were carried out on several samples arranged like illustrated in Figure 1, having a clear span of $150 \mathrm{~cm}$ and a clear rise of $50 \mathrm{~cm}$, with a width of $55 \mathrm{~cm}$ and a thickness of $7 \mathrm{~cm}$. The calcareous bricks employed are $7 \times 7 \times 15 \mathrm{~cm}^{3}$ arranged in a single sheet, with 23 rows of blocks, and bedridden with mortar of hydrated lime and cement of class M2.5 N/mm² according to Italian code. The $\Omega$-Wrap system nucleus dimensions are $5 \mathrm{~cm}$ in height and $10 \mathrm{~cm}$ in width, and it is casted on the extrados of the vault. The CFRP is placed around the core and swaged on the extrados of masonry for a width equal to $5 \mathrm{~cm}$ at each sides, and is made of two layers of uniaxial arranged at right angles to each other, forming a balanced biaxial reinforcement with equivalent thickness of $0.167 \mathrm{~mm}$ in each orthogonal directions. figure 7 shows the experimental set-up for the $\Omega$-WRAP-reinforced vaults.

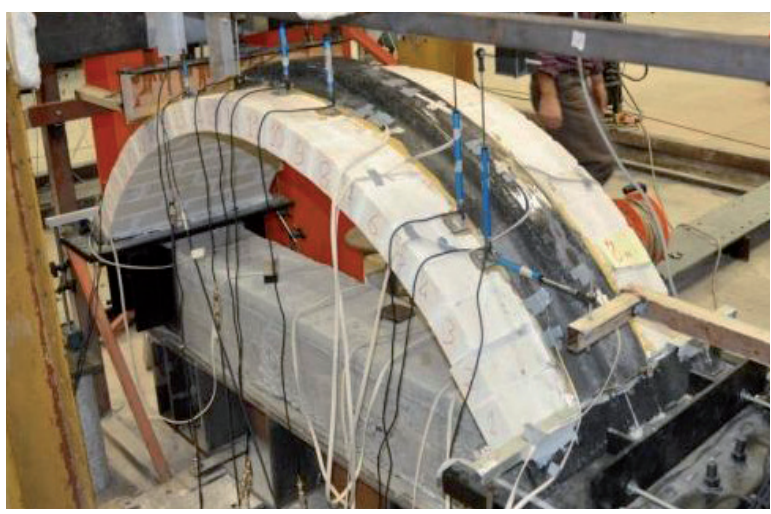

Figure 7. Experimental set-up for the $\Omega$-WRAP-reinforced vaults.

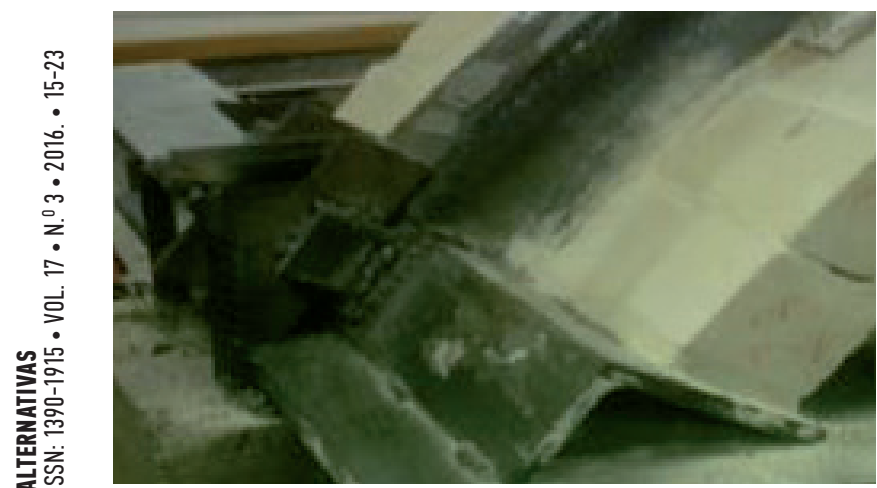

Figure 8. Shear restrain at the fixed abutment.

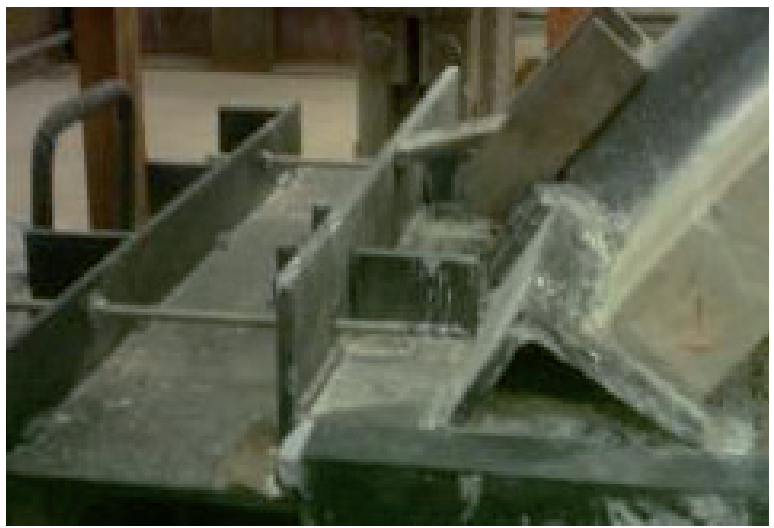

Figure 9. Shear restrain at the mobile impost.

Table 1 reports the main mechanical properties of the materials used, some of which were experimental determined, The design value of the intermediate delamination tensile strength of CFRP is determined multiplying by three the ones related to the overboard delamination, according to what prescribed by CNR-DT200/2004 for concrete.

\section{TABLA 1: MECHANICAL PROPERTIES OF MATERIALS}

\begin{tabular}{|c|c|c|}
\hline PROPERTY & MATERIAL & VALUE \\
\hline \multirow{5}{*}{$\begin{array}{l}\text { Compressive strength } \\
\text { (cubic, average) [MPa] }\end{array}$} & Brick & 12.6 \\
\hline & Mortat & 2,5 \\
\hline & Mansory & 4.1 \\
\hline & CFRP & 0 \\
\hline & Mortar of the $\Omega$-wrrap & 54.39 \\
\hline \multirow{5}{*}{$\begin{array}{l}\text { Tensile strength (average) } \\
\text { [MPa] }\end{array}$} & Brick & 1,2 \\
\hline & Mortat & 0,2 \\
\hline & Mansory & \\
\hline & CFRP & 4830 \\
\hline & Mortar of the $\Omega$-wrap core & 3,87 \\
\hline $\begin{array}{l}\text { Initial shear strength } \\
\text { (average) [MPa] }\end{array}$ & Mansory & $0,15 \div 0.20$ \\
\hline \multirow{5}{*}{$\begin{array}{l}\text { Young modulus (average, } \\
\text { secant at break point) } \\
\text { [mpa] }\end{array}$} & Brick & 9500 \\
\hline & Mortat & 675 \\
\hline & 0 & 4100 \\
\hline & CFRP & 230000 \\
\hline & Mortar of the $\Omega$-wrap core & 2882 \\
\hline \multirow[t]{5}{*}{ Density (average) [kNm-3] } & Brick & 17.5 \\
\hline & Mortat & 20.0 \\
\hline & Mansory & 18.0 \\
\hline & CFRP & 14.8 \\
\hline & Mortar of the $\Omega$-wrap core & 20.0 \\
\hline $\begin{array}{l}\text { Overboard design tensile } \\
\text { strength of CFRP with } \\
\text { different materials } \\
\text { (CNR-DT200/2004) [MPa] }\end{array}$ & Masonry & 308,7 \\
\hline
\end{tabular}


In the first series of test, in order to have a very simple failure mode, the load was applied at 1/4 of the clear span of the arch, by means of a screw jack placed in series to a load cell of $250 \mathrm{kN}$ capacity. A ball joint and a sliding bearing realized by means of two steel plates with interposed a Teflon layer of $0.3 \mathrm{~mm}$ in thickness, permits the transmission of only the vertical component of the applied load related to the imposed displacement. A tailored wood element, reinforced by means of a steel L $60 \times 6$ profile, is capable of distributing the load along the whole transversal section of the vault. A special sliding bearing support allows the measurement of the horizontal thrust by means of two cells of $25 \mathrm{kN}$ capacity located on the impost at the opposite side to the loading point. Thirteen displacement transducers are distributed along the directrix of the arch. Eight strain gauges are placed along the CFRP material as shown in figure 7.

In order to avoid shear failure at the abutments, tailored steel profiles were placed to restraint the rib of the reinforcing system (figures 8-9).The experimentally determined average load at the plateau was $38.0 \mathrm{kN}$ (figure. 10). The numerical incremental procedure gave a final result of $38.16 \mathrm{kN}$ (figure.10), with a very close accordance with the experimental data, also for the limit mechanism plotted in figures 11-12.

Other series of test was perform in a similar manner, but with an imposed displacement at the sliding abutment, imposed by means of a screw jack placed in series to a load cell of $25 \mathrm{KN}$ capacity. In this case, no load is applied at the extrados of the vault. The limit analysis method gives, also in this case, numerical results in good agreement with the experimental one. The horizontal bearing capacity of the $\Omega$-WRAP-reinforced samples result in about $17 \mathrm{kN}$ (figura. 13), that is about eight times the corresponding values of $2 \mathrm{kN}$ obtained for the unreinforced samples.

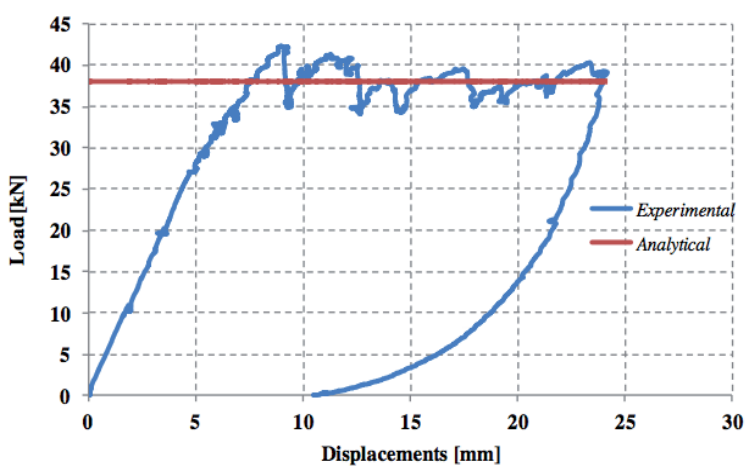

Figure 10. Testing equipment scheme.

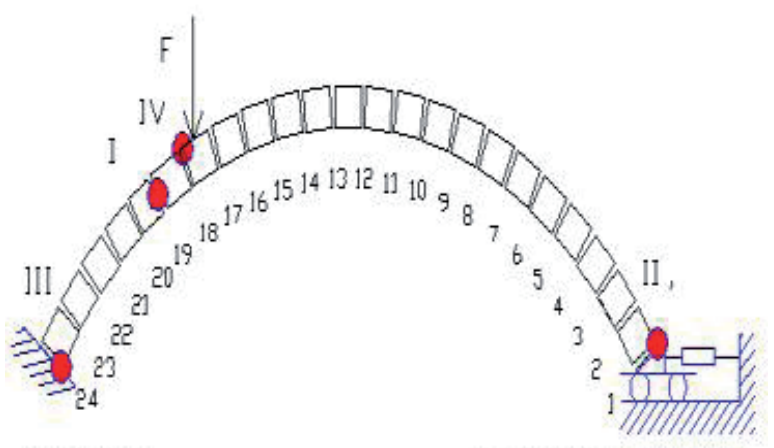

SPALLA FISSA

SPALLA MLB]LE STRUMENTATA

Figure 11. Collapse load Experimental .
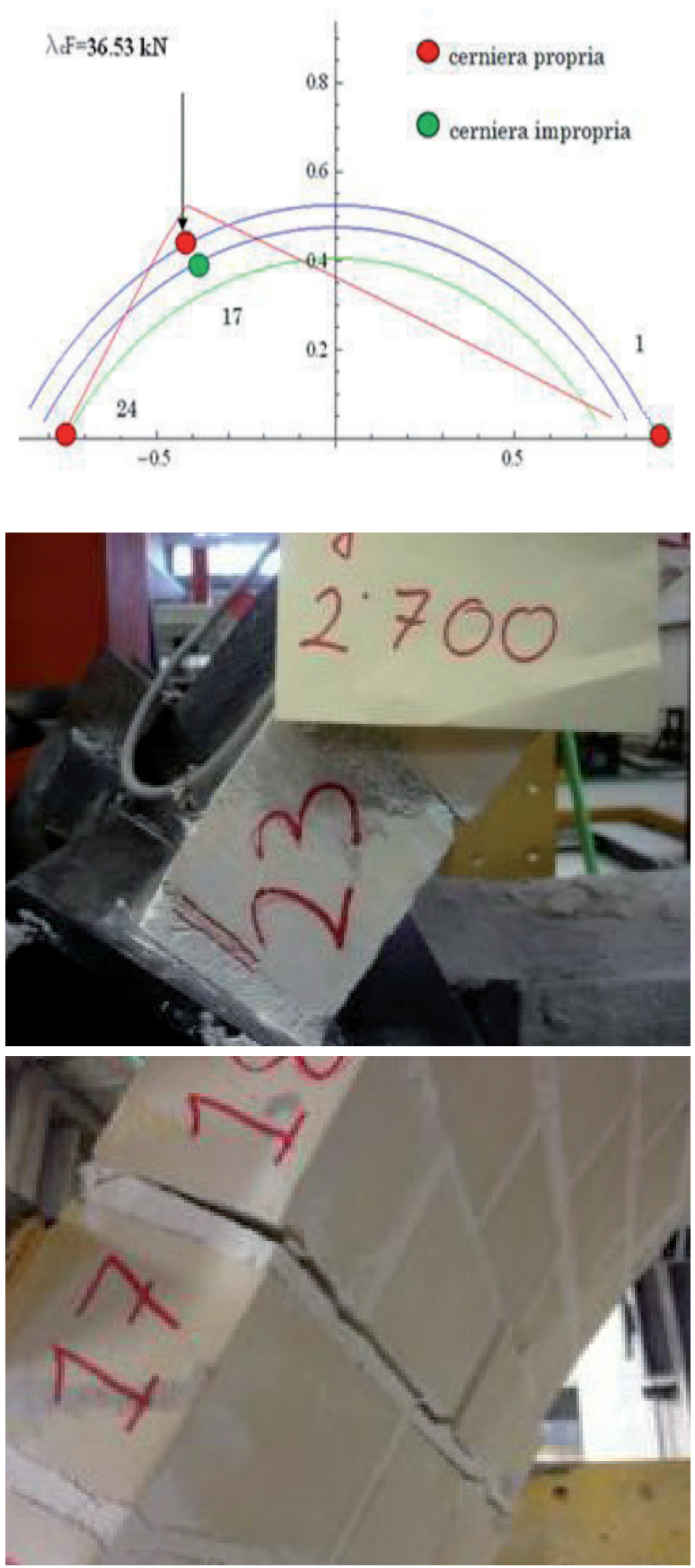

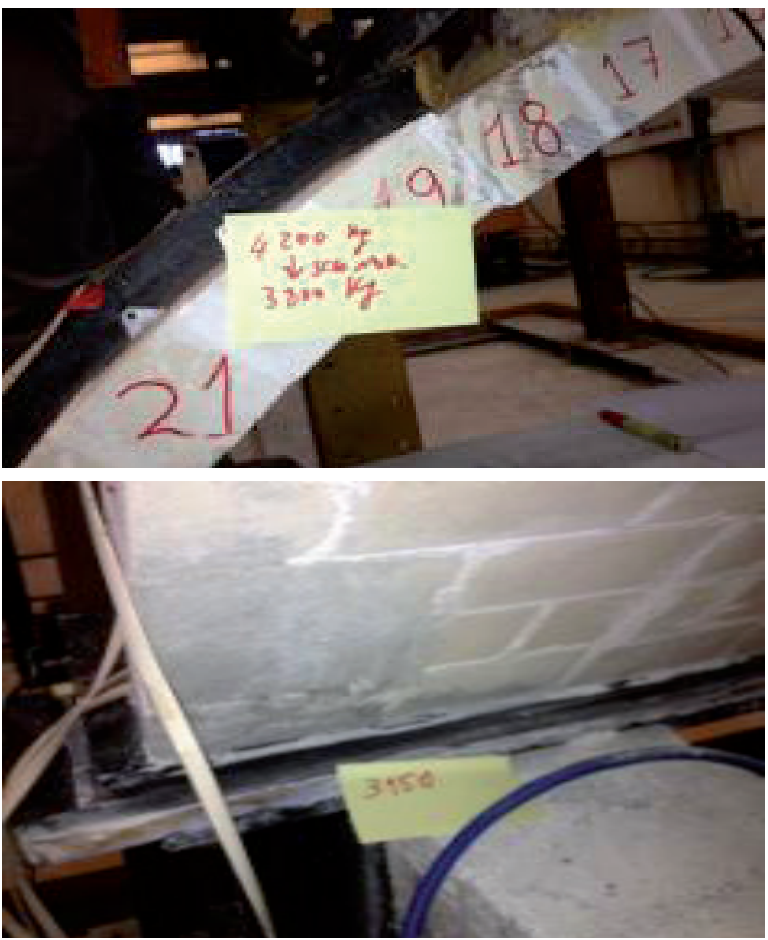

Figure 12. Comparison between theoretical and real damage in the vault.

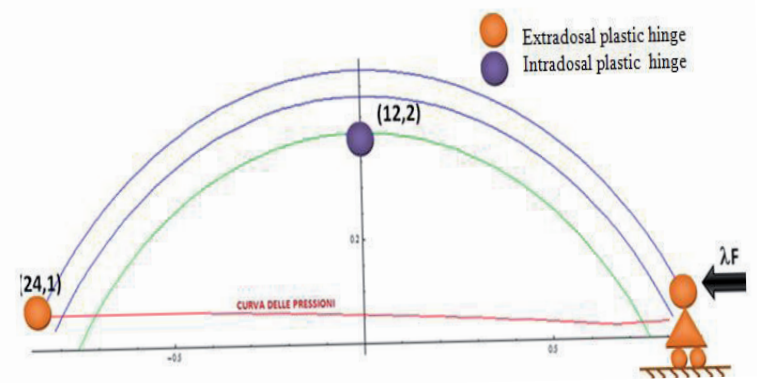

Figure 13. Theoretical collapse mechanism for horizontal load at the sliding abutment.

CONCLUSIONS

The proposed analytical procedure is able to highlights all the capability of the new strengthening technique. In fact the experimental and numerical data are in good agreement both in terms of ultimate load and collapse mode.

Besides the numerical $\mathrm{M}-\mathrm{N}$ domains show the great improvement of bearing capacity in respect to no strengthened one. In fact, a gain of more than 52 times greater is obtained. The proposed system is able to fulfill the requirement of a greater dissipation capacity for structures subjected to dynamic input if compared to the traditional strengthening systems.

The system is also capable of increasing the transferring capacity of the horizontal seismic actions among the masonry piers, useful to improve the global seismic behaviour of the entire historical building.

\section{REFERENCES}

1. Anania L., Badalà A., D'Agata G., The post strengthening of the masonry vaults by the $\Omega$-Wrap technique based on the use of C-FRP, Construction and Building Materials 47 (2013) 1053-1068.

2. CNR-DT 200/2004, Istruzioni per la Progettazione, l'Esecuzione ed il Controllo di Interventi di Consolidamento Statico mediante l'utilizzo di Compositi Fibrorinforzati-Materiali, strutture in c.a. e in c.a.p., strutture murarie. Theoretical collapse mechanism for horizontal load at the 17 $\mathrm{kN}$.

3. Basilio I., Fedele R., Lourenço P.B, Milani G., Assessment of curved FRP-reinforced masonry prisms: Experiments and modeling, Construction and Building Materials 51 (2014) 492-505.

4. D’Ambrisi A., Feo L., Focacci F., Experimental and analytical investigation on bond between Carbon-FRCM materials and masonry, Composites: Part B 46 (2013) 15-20.

5. Malena M., deFeliceG., Debonding of composites on a curved masonry substrate: Experimental results and analytical formulation, Composite Structures 112 (2014) 194-206.

6. Fagone M., Ranocchiai G., Briccoli Bati S., An experimental analysis about the effects of mortar joints on theefficiency of anchored CFRPto- masonry reinforcements, Composites PartB (2015), doi: 10.1016/j.compositesb.2015.01.050.

7. Anania L., Badalà A., D’Agata G., The behavior under thermal loads of the " $\Omega$-wrap" strategy for thestrengthening of themasonryvaultstructures, Proc. of Eleventh East Asia-Pacific Conference on Structural Engineering \& Construction (EASEC-11) "Building a Sustainable Environment, eds. Y.B Yang \& al. November 19-21, 2008, Taipei, Taiwan.

8. Mahini S.S., Eslami A., Ronagh H.R., Lateral performance and load carrying capacity of an unreinforced CFRP-retrofitted historical masonry vault - A case study, Construction and Building Materials 28 (2012) 146-156.

9. Mahini S.S., Smeared crack material modelling for the nonlinear analysis of CFRP-strengthened historical brick vaults with adobe piers, Construction and Building Materials 74 (2015) 201-218.

10. Heyman J., The Stone Skeleton, Structural Engineering of Masonry Architecture, Cambridge University Press, 1995.

11. Milani G., Valente M., Comparative pushover and limit analyses on seven masonry churches damaged by the 2012 Emilia-Romagna (Italy) seismic events: Possibilities of non-linear finite 
elements compare with pre-assigned failure mechanisms, Engineering Failure Analysis 47 (2015) 129-161.

12. Milani G., Upper bound sequential linear programming mesh adaptation scheme for collapse analysis of masonry vaults, Advances in Engineering Software 79 (2015) 91-110.

13. Milani G., Tralli A., A simple meso-macro model based on SQP for the non-linear analysis of masonry double curvature structures, International Journal of Solids and Structures 49 (2012) 808-834.

14. Milani G., Simoni M., Tralli A., Advanced numerical models for the analysis of masonry cross vaults: A case-study in Italy, Engineering Structures 76 (2014) 339-358.

15. Basilio I., Fedele R.,. Lourenço P.B, Milani G., Assessment of curved FRP-reinforced masonry prisms: Experiments and modeling, Construction and Building Materials 51 (2014) 492-505.
16. Block P., Lachauer L., Three-dimensional funicularanalysis of masonry vaults, Mechanics Research Communications 56 (2014) 53-60.

17. Fraternali F., A thrust network approach to the equilibrium problem of unreinforced masonry vaultsvia polyhedralstress functions, Mechanics Research Communications 37 (2010) 198-204.

18. Baratta A., O. Corbi, Closed-form solutions for FRP strengthening of masonry vaults, Computers and Structures 147 (2015) 244-249.

19. Badalà A., Cuomo M., D’Agata G., Limit Analysis Of CFRP Reinforced Masonry Vaults: An Appoximated Incremental Algorithm GIMC 2010.

20. Badalà A., Cuomo M., D’Agata G., Analisi limite di volte a botte rinforzate con C-FRPAIMETA2009-Ancona, 14-17 Settembre, 2009.

21. Italian Code D.M.14/01/2008 - Approvazione delle nuove norme tecniche per le costruzioni. 